

Vol 6, No 1 "Boundless" (2017) | ISSN 2153-5914 (online) | DOI 10.5195/contemp.2017.186

http://contemporaneity.pitt.edu

\title{
The Internal Frontier \\ How Art at Once Problematizes Borders and Draws Us Closer to Them
}

Kasia Ozga

\begin{abstract}
This study combines first-person storytelling, visual interpretation, and linguistic investigation to analyze how a mixed-media artwork that Kasia Ozga produced in 2011, The Internal Frontier, represents immigrant journeys on an autobiographic, social, and discursive level. In the context of an increasingly polarized political climate, Ozga examines borders as individual experiences and geopolitical phenomena to explain how art conditions conflictual aspects of the self to coexist, promoting social consciousness and community engagement.

Those in power use borders to naturalize and separate what is familiar from what is strange. As an artist, Ozga explores how our personalities are partitioned, enforced, and made from external boundaries that define our movements, and by the internal borders that we impose on ourselves. Here, reproductions of different "frontiers" around the world are literally cut from the fabric of human chest $x$-rays collected from immigrant long-term visa applicants, highlighting physical removal and absence. To produce these modified artifacts, shown in light-boxes in various exhibitions in France and the United States, Ozga researched the border-as-process of inclusion and exclusion linked to regulative authority in social relations, nation-building, political sovereignty, as well as personal identity formation.

In the artworks, migration is transformed from an isolated act to a shared human experience. The images, at once precise and indeterminate, maintain the dual symbolism of the border as barrier and as springboard, simultaneously inhibiting and enabling interactions between individuals and select geographic locations. Just as migrants lead us to re-evaluate our physical and mental borders, critical cultural production can contest the impact and staying power of borders by underscoring how establishing and overriding boundaries enable us to claim and reclaim who we are.
\end{abstract}




\section{The Internal Frontier How Art at Once Problematizes Borders and Draws Us Closer to Them}

\author{
Kasia Ozga
}

(AWAY FROM IT ALL)

HERE THERE \& EVERYWHERE

(BENEATH IT ALL)

HERE THERE \& EVERYWHERE

(ALL OVER IT ALL)

HERE THERE \& EVERYWHERE

(ABOVE IT ALL)

HERE THERE \& EVERYWHERE

Lawrence Weiner ${ }^{1}$

As an immigrant, I am interested in the spaces between the ideals of open and closed borders and the geographic organization and psychological impact of these opposing paradigms. As an artist, I share Jane Rendell's conviction that the function of art is its critical role within the public sphere, and in particular its capacity to ask questions about how we occupy public places. ${ }^{2}$ While borders have been intimately tied to my identity, I rarely addressed them in my art before producing a series entitled The Internal Frontier (La Frontière Interne) during an artist residency on the French and Spanish border in 20102011. My desire to give form to the immaterial effects of this social and geographical construct was prompted by my body's daily physical confrontations with a border to which I had no prior personal connection.

In this paper, I analyze how the artworks represent immigration on an autobiographic, social, and historical level. I first describe how they portray border passages and transgressions by combining paper cutting techniques with medical imaging. Later, I explore how borders, both as geopolitical phenomena and as building blocks of identity, inform my work. Finally, I foreground various philosophical and linguistic conceptions of borders evoked by the series, to consider the disparate experiences of border crossers in different sociopolitical contexts. I conclude by analyzing how visual art can encourage dialogue on border policy by enabling various conflictual aspects of identity to coexist, promoting social consciousness and community engagement.

\section{Representing Borders}

Through visual art, I explore how our identities are partitioned, enforced, and made from external boundaries that define our movements and by the internal borders that we impose upon ourselves. The Internal Frontier series juxtaposes recent visual evidence of the interior anatomy of various male and female human bodies with reproductions of different "frontiers" around the world. The works were initially created at NEKaTOENEa, an artist residency in the Domaine d'Abbadia in Hendaye, in the Basque Country in 2010-2011, right before the dawn of the Arab Spring and subsequent civil war in Syria. The artwork addresses borders as political institutions and corporal experiences, rather than as mere territorial markers.

\footnotetext{
${ }^{1}$ Lawrence Weiner, HERE THERE \& EVERYWHERE, language and the materials referred to, dimensions variable (Whitney Museum of American Art, New York, 1989).

2 Jane Rendell, Art and Architecture: A Place Between (London: I.B. Tauris, 2008), 156.
} 


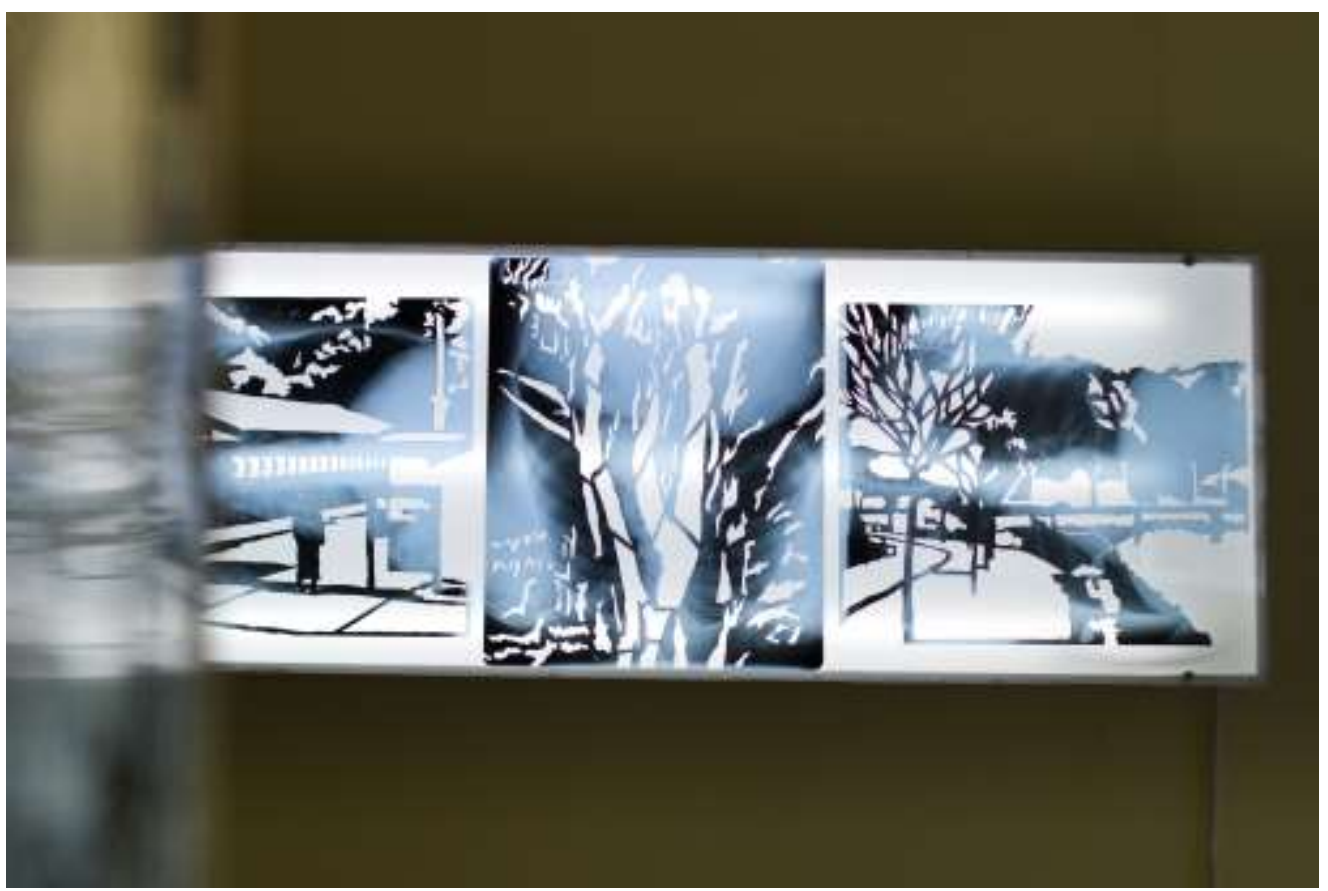

\section{Figure 1}

Kasia Ozga, Internal Frontier I and II, 2014, X-ray film on medical lightbox. Installation view, La Nuit de I'Instant 2014, Marseille, France. (photo: author)

The series consists of cutouts made from human x-rays, displayed on medical-grade light boxes. Like most developed countries, France requires non-EU immigrants seeking longterm residency permits to obtain chest $\mathrm{x}$-rays in order to get cleared for processing. This form of physical screening was initially introduced for public health reasons: to prevent outbreaks of tuberculosis. Every day, governments assert their right to view and catalogue the innermost parts of immigrants' bodies to determine who gets to stay within their borders and who is unfit to remain. ${ }^{3}$ The $x$-rayed body is examined by the medical establishment and reduced to an object of study. Even when informed consent is obtained, this penetration of the body by the state via medical imaging is a highly symbolic act, imposing authority and commanding deference. ${ }^{4}$ The automated procedure obscures the intimacy of what takes

3 This procedure is used by many nations-including the United States-that screen immigrants for TB. Kevin Schwartzman and Dick Menzies, "Tuberculosis Screening of Immigrants to Low Prevalence Countries. A Cost-Effectiveness Analysis," American Journal of Respiratory and Critical Care Medicine 161, no. 3 (2000): 780-89. EU countries often, and controversially, resort to radiographic examinations of the teeth and skeletons of asylum applicants as a means of age assessment. Al Aynsley-Green, Tim J. Cole, Heaven Crawley, Nick Lessof, Louise R. Boag, and Rebecca M. M. Wallace, "Medical, Statistical, Ethical and Human Rights Considerations in the Assessment of Age in Children and Young People Subject to Immigration Control," British Medical Bulletin 102, no. 1 (2012): 17-42. doi:10.1093/bmb/lds014

${ }^{4}$ Indeed, Britain's borderguards used x-rays to scan trucks suspected of ferrying migrants through the Chunnel until the procedure was banned in 2016, and police have deployed similar technology at checkpoints in South-Eastern Mexico. 
place: each immigrant is required to trade a detailed image of his or her inner anatomy to the State in exchange for a new identity card. In my artwork, each x-ray, denoting a specific person's experience, becomes an anonymous symbol of this process as the surveillance itself is exposed to public scrutiny.

The personal is political: my own chest was scanned and photocopied in an assemblyline-style intake center in the suburbs of Paris in 2007, before Polish citizens became full European Union members. Shortly thereafter, I asked fellow immigrants who had kept their $\mathrm{x}$-rays as souvenirs of the country's notorious bureaucracy to donate them for use in Entrez! (Enter!), a public video art installation made for the 2009 Ici et Demain Festival in Paris in collaboration with Emilie McDermott. In that work, anonymous x-rays were taped together to form a three-meter-tall temporary tunnel through which visitors were forced to walk. The passage, designed to be shown inside a student center for foreign researchers, included a video of individuals walking back and forth across a bridge projected underfoot, symbolizing the nonlinear nature of the immigrant experience. Once the project was over, I incorporated the $\mathrm{x}$-rays into my subsequent artworks as a discrete medium.



\section{Figure 2}

Kasia Ozga, Internal Frontier I, 2014, Xray film on medical lightbox, $35.5 \times 43 \times$ $10 \mathrm{~cm}$. Installation view, Land Grab Exhibition, The Mission, Chicago, Illinois.

(photo: author) 
The idea of literally cutting apart x-rays came about by accident. One day, as I was removing the plastic fire-retardant film used to hold the images in place for the installation Entrez, the x-rays ripped apart. I grew interested in seeing the photographic medium itself as a material that could be surgically manipulated. Thus, I researched papercutting, a form of decorative art present in diverse cultures around the world for over 2,000 years. ${ }^{5}$ By drawing projected images on the $\mathrm{X}$-rays and then cutting them out with an X-Acto knife, I was able to physically juxtapose a representation of a particular body at a particular moment with an image of another place and time. Rather than a mere layering and merging of two images via Photoshop or double exposure, each scarred double image highlights physical removal and absence, formally emphasizing displacement as a process that has lasting consequences for our bodies and ourselves.

The Frontière Interne is not a visual illustration of a theoretical treatise on borders but rather a poetico-plastic exploration informed by sensory experiences and intellectual reflection. Representations of borders depend just as much on formal qualities (the paper on which they are printed and the contexts in which they are displayed and reproduced) as they do on visual content. The Frontière Interne is divided into two series of artworks that alternately include abstract close-up and iconic landscape imagery. The first group, Frontière Interne $I$, consists of nine vertical images cut out of standard-size chest $\mathrm{x}$-rays, each measuring $35.5 \times 43 \mathrm{~cm}$. Each piece can be displayed in a separate light box. Abstract images of plants, such as ferns, and landmarks photographed along the physical border zone between France and Spain are cut out of the x-rays of immigrants currently living in France. The second group, Frontière Interne II, consists of twelve horizontal images cut out of chest x-rays, each measuring $43 \times 35.5 \mathrm{~cm}$, also displayed in light boxes. This time, the works juxtapose the $x$-rays with cutout images of various borders and conflict zones around the world. Some of these images directly relate to the personal histories of the individuals who donated their images. All are distilled from found border photographs posted online and obtained via Internet search engines.

Being on an open border such as the one separating Hendaye from Irun reveals the artificiality of all borders. As philosopher Étienne Balibar explains, "There have never existed, anywhere, 'natural borders,' that great myth of the foreign policy of nation-states. Everything here is historical." ${ }^{6}$ I photographed the source imagery for Frontière Interne I during months that I spent living in an area where walking back and forth across a field allowed me to move between two different countries. This was the first time I had lived in a border zone. The sand swirling along the coast paid no heed to which nation it landed in as the tide came in. The physical space of the border existed in sharp contrast to aerial maps, satellite photos, and GPS signals that identify a specific area as the border; neither here nor there. The real border was more political and institutional than cultural and palpable. ${ }^{7}$ This understanding led me to trace and remove shapes found in the physical border from the $\mathrm{x}$ -

${ }^{5}$ Contemporary paper cutout artists include Béatrice Coron, who creates highly detailed stories using this technique; David Thorpe, who layers papers to create photorealistic dystopian science fiction scenes that feel like relief maps; and Kara Walker, whose life-size, socially engaged wall pieces explore slavery and the African American experience to understand how foreground and background contribute to a specific understanding of narrative and place.

6 Étienne Balibar, We, the People of Europe: Reflections on Transnational Citizenship, trans. James Swenson (Princeton, NJ: Princeton University Press, 2004), 109.

7 Étienne Balibar, Politics and the Other Scene (London: Verso, 2002), 89. 
rays I had brought with me-material artifacts of the border-as-process of inclusion and exclusion.

The works in Frontière Interne $I$ are often more abstract than those in the second series while, at the same time, more directly related to my personal physical experience of one specific border. Organic forms dominate with vegetal motifs, wooden branches, leaves, raindrops, and clouds covering and obscuring the precise scientific prints of sternums and clavicles. These forms are artifacts of my meandering within the border zone that appear generic, as though they could have come from anywhere, just as the term "border town" obscures the specific realities of such spaces. ${ }^{8}$ I juxtaposed the symmetry of the bone structure and chest cavities revealed by the $\mathrm{x}$-rays with asymmetrical twigs and reeds, at once covering and sprouting from limbs and ribs. Because the sticks' silhouettes do not specify where they come from, the images imply that borders potentially exist anywhere and everywhere. The source photos were mainly taken with my camera pointing down at the ground: the space in which physical border walls were planted and to which passageways were tethered, when this particular border was actively policed before the implementation of the Schengen Agreement in 1995. Like flat wallpaper patterns recalling the forms of Matisse's gouache on paper cut-outs, they hint at and reveal the textures of each subject without proffering a clear context or location. These motifs do not provide any obvious indication as to which view of the x-ray is "right side up." Rather, the orientation of the works comes from the placement of the human skeleton in the background image.

The second series, Frontière Interne II, has more narrative content: cutout landscapes portray borders around the world, some tense, others peaceful. Several images contain the silhouettes of people: border control officers, soldiers, children, and marchers in a procession. Vehicles and architectural forms include fences, gates, and passageways copied from images of the US-Mexico, US-Canada, Poland-Ukraine, Israel-Jordan, the Korean DMZ, and other historic border crossings alluded to by the geographic coordinates in the works' titles. Because they are less abstract, and depict identifiable if not familiar locations, these works invite viewers to imagine specific narratives or experiences related to the passage between one country and another.

Before being formally exhibited, the artworks were reproduced in a bilingual French/Basque catalogue, Borders, barrières, frontiers (2013), with an essay by the curator, Alexandra Baurès. Though I had intended to display the works independently in identical steel light boxes, I often ended up grouping them together in practice, to produce entirely different narratives. X-ray cut-outs aligned next to one another on a long horizontal illuminator invite comparisons that allude to changes over time and space, as the cut-out images indicate different physical states and pathologies. When works from the second series are shown alongside works from the first, they act as establishing shots in a film, setting the scene for the "close ups" next to which they are placed. A detail of a hole ripped through a chain-link fence, an image of soldiers patrolling a hillside, and a second detail of a cloud formation in the sky, for example, could combine to suggest a clandestine passage. The order in which the works are shown is constantly changing: they were exhibited in different configurations in an individual exhibition, La Off \#3: Borders/Barrières/Frontières, at the Centre Culturel Saint-Exupéry, Reims (2013), in a group exhibition, La Nuit de l'Instant, in

\footnotetext{
8 Marc Augé, Non-Lieux (Évreux : Éditions du Seuil, 1992).
} 
Marseille, France (2014), and in an individual show at The Mission gallery in Chicago, Illinois, entitled Land Grab (2014) ${ }^{9}$.

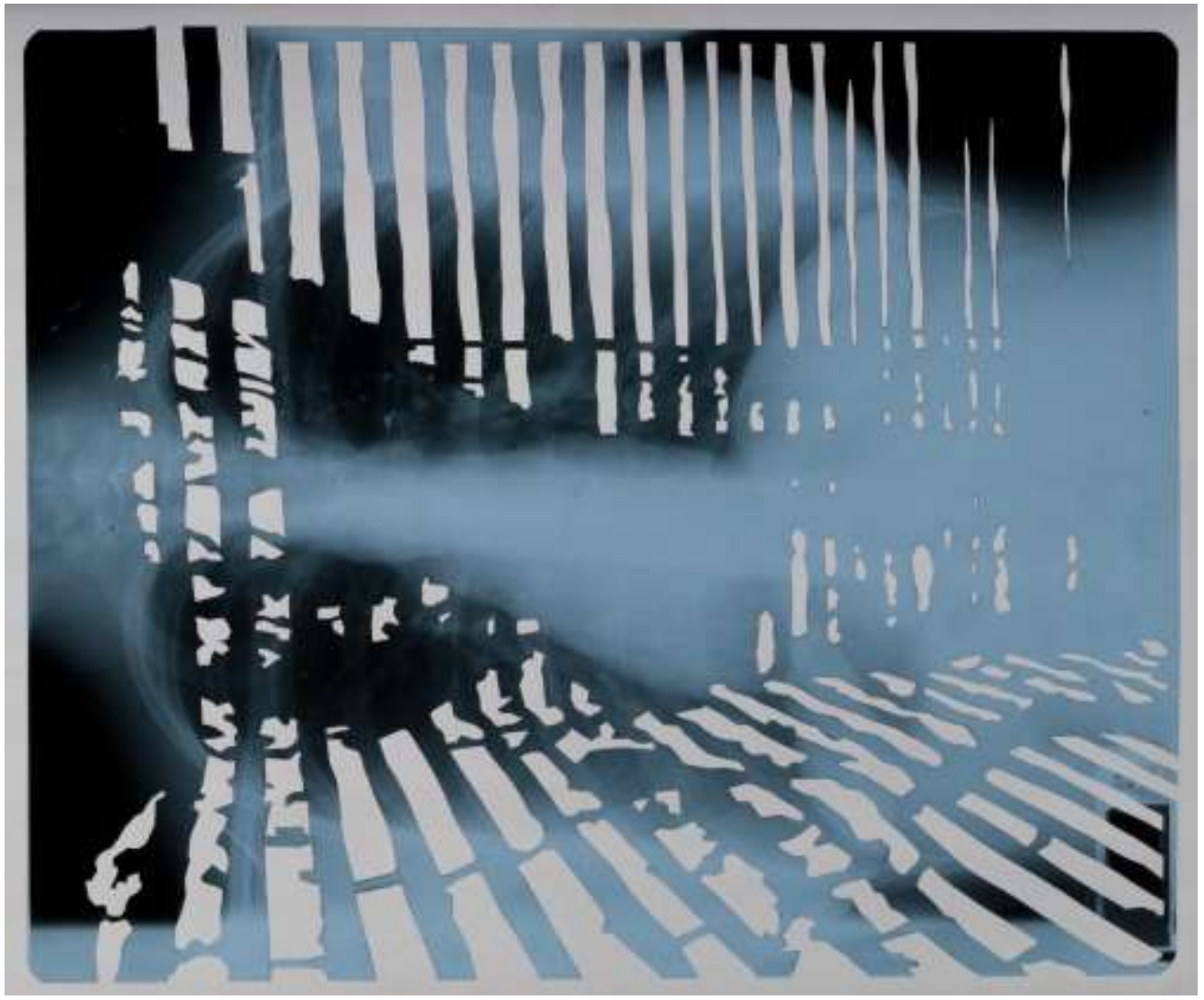

\section{Figure 3}

Kasia Ozga, Internal Frontier II $32^{\circ} 32^{\prime} 03.7^{\prime \prime} \mathrm{N} 117^{\circ} 07^{\prime} 25.5^{\prime \prime} \mathrm{W}, 2014$, X-ray film on medical lightbox, 35.5 x $43 \times 10 \mathrm{~cm}$. Installation view, Land Grab Exhibition, The Mission Gallery, Chicago, Illinois. (photo: author)

\section{Access to Possible Futures}

The series was motivated by empathy with the challenges many foreigners face, frustration with the unfairness of the global birthplace lottery, and a coming-to-terms with my own privileged experiences as an immigrant in France and in the United States. Borders symbolize opportunities that prove illusory for many immigrants. I highlight the divide between the romantic ideal and the reality of modern-day border crossing by connecting official imagery with personal representations. The work launches an inquiry via imagination,

${ }^{9}$ They were also discussed during a lecture at the Staatliche Akademie der Bildenden Künste Stuttgart on 06/21/16 and profiled in the Electronic Journal for Visual Culture, InVisible Culture (IVC), published by the University of Rochester. K. Ozga, "Internal Frontier," IVC 22, no. 1 (04/18/2015), https://ivc. lib.rochester.edu/internal-frontier/ 
posing questions as a way of opening up possibilities for reflection, suggesting-rather than specifying-what a border is and should be.

While the notion of borders is often linked to nation-building and political sovereignty, such barriers intimately affect personal identity. In my own case, border crossing was both an imposed experience in my youth and a personal choice in my adult life. I was born a few months before the declaration of martial law in Poland, a country with one of the largest diasporas in the world, where "brain drain" is a recurring political issue. ${ }^{10}$ In the early 1980 s, the then-People's Republic of Poland $(P R L)$, part of the Eastern Block and within the Soviet sphere of influence, was on the cusp of transforming its government and relations with its closest neighbors. For reasons both economic and political, my parents decided to emigrate abroad when I was a toddler. Once my mother secured a postgraduate internship in an architecture studio in Berlin, she left communist Poland alone to go to then-West Berlin on a temporary visa. For months, she drew the façades of buildings from blueprints and observation, despite not speaking the language. My father and I received permission to join her six months later.

Border crossings are constantly shifting passages that appear solid and immutable. Stories about the difference between Eastern and Western Europe, and the then-perilous passage between the two, were a fixture of my childhood. My grandmother told me about the border guards in watchtowers slowly observing each train car that passed below, cradling assault rifles and sowing fear among passengers who hid family heirlooms and American dollars in jars of Bigos, a savory home-made Polish stew. She told me about the large dogs that obediently followed the guards examining passengers for possible smuggling, her smiles through clenched teeth as I, a boisterous three-year-old child, casually chatted with our fellow passengers about my imminent departure from a country in which the very act of obtaining a passport was near-impossible for most of the population. She remembers the sinking feeling of knowing she might never see her son again as well as the shock and recognition at each detailed letter he sent back home, describing his new life. Twenty years later, I rediscovered these letters and experienced the opposite kind of shock: the intervening years had so transformed both the border itself and my father as to render his words about his new home barely recognizable. Since the 1980s, Poland has been inching from East to West, aspiring to the living standards and wealth of its EU neighbors, and the gulf between it and the United States has narrowed to that of an admittedly unequal, banal bilateral relationship.

Borders are always political, but not necessarily cultural and linguistic. My parents were obliged to study Russian, even in university. However, my mother had also learned French and dreamed of ending up in France or Québec. At that time, legal immigration to Western Europe was not an option. In Berlin, my parents were denied political asylum to Canada, Australia, and South Africa. After sweating under uncomfortable woolen business attire in embassy after embassy, they decided to dress casually for the visa interview to the United States. To this day, my father credits their move to the United States to Ronald Reagan's largesse and to the 80 s-style tracksuits they wore that day.

Crossing a border implies agreeing to the host country's terms. Despite the apparent separation between church and state, Polish immigrants in the 1980 s needed a sponsoring organization to settle in the United States and most were religiously affiliated. We landed in a

10 Up to twenty million people of Polish ancestry live abroad, compared to the country's current population of thirty-eight million. Polish Ministry of Foreign Affairs, Polish Diaspora, http://www.msz.gov.pl/en/foreign_policy/polish_diaspora/ 
small town (Springfield, Missouri) in the open arms of a local church, even though my family of atheists had traditionally rejected religious affiliations. The church, the daycare center, and the office became sites for cultural and linguistic assimilation, where old behaviors were discouraged and new walls were erected. Internalizing new cultural codes went hand in hand with creating an American identity. ${ }^{11}$

In my childhood, a border symbolized possibility, not a barrier that was inevitably either open or impenetrable, but a door that could be pushed ajar with the right combination of cunning and luck. I grew up pledging allegiance to the American Flag and attending Polish school on Saturdays in the Chicago suburbs. I went to college in Boston, graduate school in Poland, and completed my PhD in France, where I now live-in a twist of fate-thanks to my Polish passport rather than my American identity papers. With my own roots spread over two continents, I code switch constantly, continually changing how I relate to and represent national allegiances. Despite the hardships that my parents and I faced when I was young, I am incredibly lucky to have gained the freedom to choose where I live. I was and am able to circulate in a world where it is relatively easy for me to traverse national borders.

Others are not so fortunate.

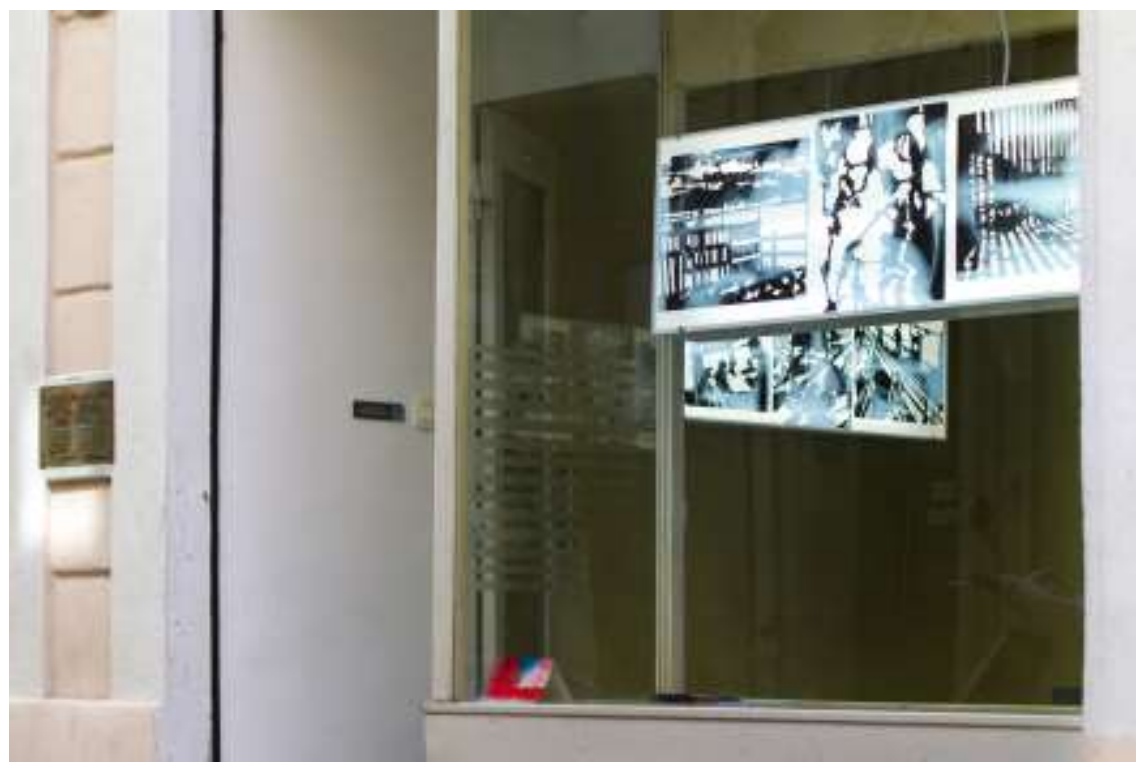

\section{Figure 4}

Kasia Ozga, Internal Frontier I and II, 2014, X-ray film on medical lightbox. Installation view, La Nuit de I'Instant 2014, Marseille, France. (photo: author)

11 Charlotte Burck, Multilingual Living: Explorations of Language and Subjectivity (New York: Palgrave Macmillan, 2005), 76-79, 85. 


\section{Borders as Limits}

Border control is a form of power. "Borders, far from serving merely to block or obstruct global passages of people, money, or objects, have become central devices for their articulation." ${ }^{12}$ Resources and opportunities are not equally distributed around the world, and scholars have long pointed out the disparity between how nations treat goods versus how they treat human capital. ${ }^{13}$ At the same time, as we abolish tariffs and promote free trade, we increase restrictions on cross-border travel, making it harder to legally move about and work far from home-unless one is part of a privileged, educated class hailing from the global north. If my parents were not Polish in the early 1980 s but Mexican or Syrian or Nigerian in 2017, we might never have gotten a visa to enter the United States, let alone a green card (permanent residency permit), and, ultimately, American citizenship. Even among those in our situation, we were the lucky ones. Three-fourths of the Poles who immigrated to the United States in the 1980s did not obtain asylum, but rather overstayed short-term visitor visas and were forced to work illegally in the underground economy, limiting their ability to anticipate the future. ${ }^{14}$

When identities are fixed, people are stuck both physically and mentally, anchored to physical sites and behavioral norms; their agency is limited. Not all places offer equal opportunity and hospitality. Many would-be migrants are mired permanently on the outside, unable to join the club of privileged visa holders and to change their situation and the imposed cultural norms framing and essentializing their identities. Permanently leaving one's home can be a long and fraught process of confronting and overcoming various limitations. While a minority of the world's people are technically migrants, the migrant experience affects all humans as a cultural archetype and political reality. According to the United Nations Population Fund, in 2015 , only $3.3 \%$ of the global population lived outside of its country of origin. ${ }^{15}$ This figure includes all migrants-refugees, economic migrants, and asylum seekers, immigrants and expats alike. According to the United Nations High Commissioner for Refugees, there are sixty-five million forcibly displaced people worldwide, including twenty-one million refugees, fleeing armed conflict, persecution, natural disasters, death, imprisonment, torture, starvation, poverty, or disease. ${ }^{16}$ These people have abandoned their homes yet cannot move about freely; they do not have the necessary papers, authorizations, and financial means to do so. The largest single group of refugees comes from Syria. Many are trapped in limbo in "temporary" camps for years at a time, where boundaries are imposed by the outside rather than embraced from within. According to a study by the Overseas Development Institute, the duration of refugee displacement is currently increasing, with over half of refugees being displaced for over four years, and over

12 Sandro Mezzadra and Brett Neilson, Border as Method: or, the Multiplication of Labor (Durham, NC: Duke University Press, 2003), ix.

13 Antoine Pécoud and Paul de Guchteneire (Eds.), Migration Without Borders: Essays on the Free Movement of People, (UNESCO, 2007) and Charles B. Keely, Globalization Transforms Trade-Migration Equation (Washington, DC: Migration Policy Institute, 01/12/2002).

14 Dominic A. Pacyga, "Polish Diaspora," in Encyclopedia of Diasporas, eds. Melvin Ember, Carol R. Ember, and Ian Skoggard (New York: Springer, 2005), 254-63.

15 United Nations Population Fund, Migration, 2015, http://www.unfpa.org/migration

${ }^{16}$ Adrian Edwards, "Global Forced Displacement Hits Record High," UNHCR, http://www.unhcr.org/en-us/news/latest/2016/6/5763b65a4/global-forced-displacement-hits-recordhigh.html 
a third for over ten years! ${ }^{17}$ The state of being permanently in transit can represent a lifestyle choice for ex-pats or an impossible burden for displaced people. Many long to escape war for peace, not to keep running for years on end. Political movements such as the Dreamers in the United States, NO Border, or L'Action des chrétiens pour l'abolition de la torture (ACAT), and social practice artworks like Tania Bruguera's Immigrant Movement International seek to transform and revolutionize current border control regimes, encouraging solidarity across these barriers while governments around the world increasingly impede refugee resettlement. With the Internal Frontier, I raise awareness of limitations on international mobility, encourage viewers to reflect on immigration as a product of both desire and necessity, and condemn the othering of the immigrant body that takes place amid a culture of intensifying nationalism.

The possibilities and limitations national borders represent are compounded by cultural factors that are themselves immaterial boundaries enabling and rejecting various expressions of identity. A boundary is "at once a geographical marker and a geographical maker of regulative authority in social relations," encouraging some behaviors and discouraging others. ${ }^{18} \mathrm{~A}$ border's restrictiveness depends on where one stands in relation to it. As any sports fan (Polish kibic) will tell you, borders that appear closed and oppressive to the outside can, on the inside, enable discovery, creativity, and fellow feeling. Cultural boundaries such as gender binaries frame how male and female children are socialized differently. However, these social borders can and do evolve. As writer Agnieszka Graff observes, traditional arrangements between the sexes increase in the context of political, social, and economic crisis. ${ }^{19}$ Political power regulates cultural factors to limit our capacity to struggle against the borders that are imposed upon us. At the same time, we can choose not to internalize these borders via passive, nonviolent resistance or overt contestation.

Critical cultural production can affirm facets of identity overlooked or suppressed by normative values, contesting the impact and staying power of borders that will not and cannot be closed forever. The Internal Frontier series posits that encountering immigrants and exploring border regimes informs our identities. Raising awareness of the human dimension to these geopolitical markers can help undermine them. In the series, each anonymous, identically proportioned $\mathrm{x}$-ray is hand-carved with a personal, individual motif. Rather than being another number in a residency card application file, each immigrant is shown as having a story to tell, an experience to share. At the same time, that story is not

17 Nicholas Crawford, John Cosgrave, Simone Haysom, and Nadine Walicki, "Protracted Displacement: Uncertain Paths to Self-Reliance in Exile," September 2015, Humanitarian Policy Group, https://www.odi.org/sites/odi.org.uk/files/odi-assets/publications-opinion-files/9851.pdf

18 Matthew Sparke, "Boundary," in The Dictionary of Human Geography, 5th ed., ed. Derek Gregory, Ron Johnston, Geraldine Pratt, Michael Watts, and Sarah Whatmore (Singapore: Wiley Blackwell, 2009), 55.

19 Agnieszka Graff, Świat bez kobiet. Płeć w polskim życiu publicznym (A world without women: gender in Polish public life) (Warsaw: WAB, 2001). In Poland, as inequality between rural and urban areas widened after the fall of communism, so did restrictions on family planning services. In the United States, a decrease in women's participation in the labor force since 1999 occurred amid the rise of restrictions on women's health services. OECD (2016), "Labour Market Statistics: Labour Force Statistics by Sex and Age: Indicators," OECD Employment and Labour Market Statistics (database), http://dx.doi.org/10.1787/data-00310-en, accessed October 23, 2016. Elizabeth Nash, Rachel BensonGold, Zohra Ansari-Thomas, Olivia Cappello, and Lizamarie Mohammed, "Laws Affecting Reproductive Health and Rights: State Trends at Midyear, 2016," Guttmacher Institute, July 21, 2016, https://www.guttmacher.org/article/2016/07/laws-affecting-reproductive-health-and-rights-state-trendsmidyear-2016 
fixed. Indeed, according to postcolonial scholar Edward Said, "[T]he art of memory for the modern world [is] something to be used, misused, and exploited, rather that something that sits inertly there for each person to possess and contain." 20

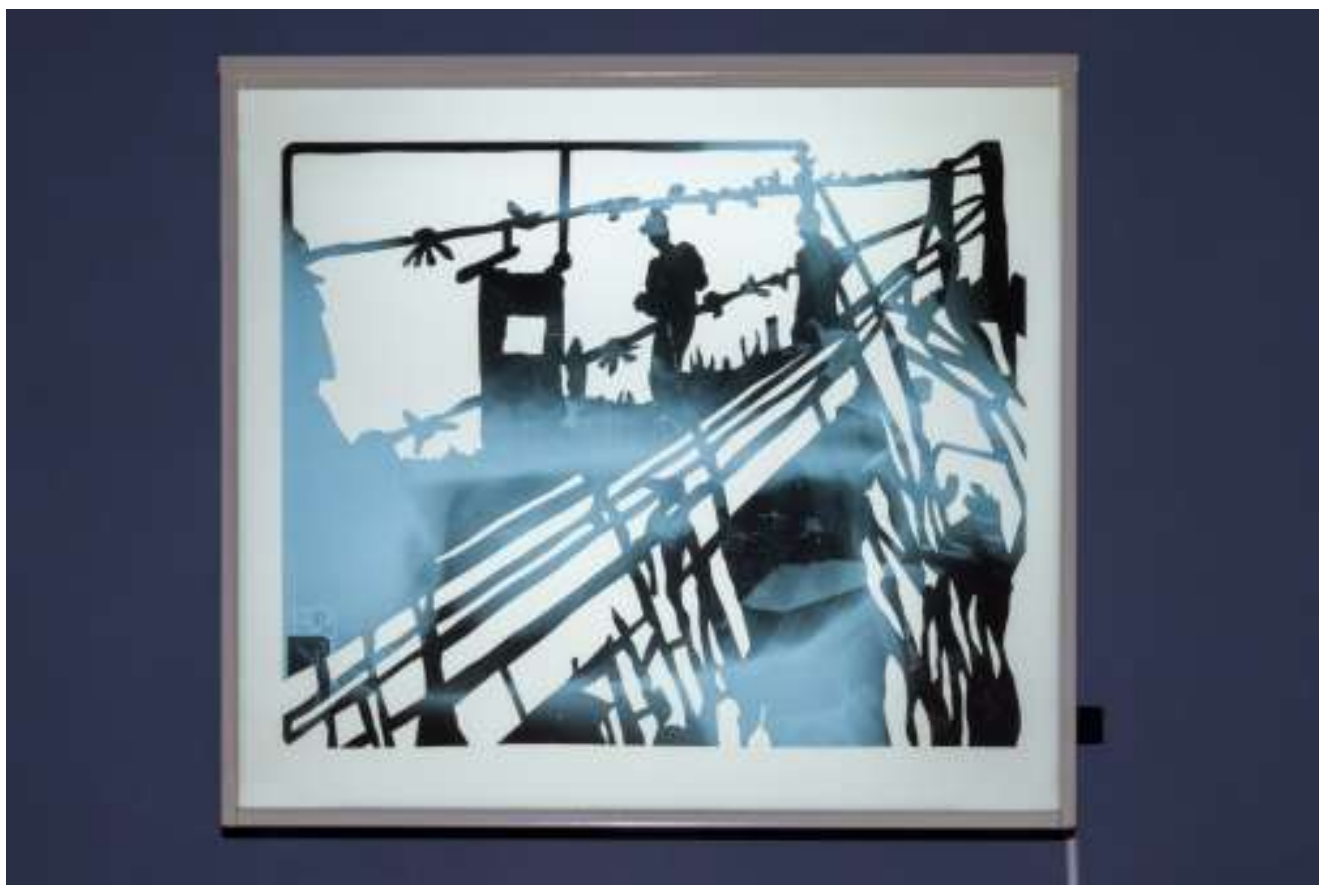

\section{Figure 5}

Kasia Ozga, Internal Frontier II 52 $01^{\prime} 54.3^{\prime \prime} N$ 2339'33.4"E, 2013, X-ray film on medical lightbox, 43 x 35.5 x 10 cm. Installation view, Borders: Barrières Frontières La Off \#3 Exhibition, Centre culturel numérique Saint-Exupéry, Reims, France. (photo: author)

Depicting the toll of migrant experiences on the human body enables viewers to connect with immigrants through a universally recognizable form. The body is a physical system existing in time and space with a social presence. The body is not confined to the material within our skin, but it requires this boundary to function mentally and socially, to activate spaces and situations. X-rays and photographs can document the body inside and out at a specific moment in time; however, the former usually reveal little about the body's specific social context. Our environment affects our bodies and our identities. Our relationships to borders shape who we are; a child refugee in a camp for displaced persons will have a different sense of security than a child raised in a predictable environment with limited, and rarely life-threatening, conflict. In the Frontière Interne series, the experience of a specific border environment is a signifier of social existence engraved on a medical scan of an immigrant's body. The identity of each person is represented by the interplay between the body and the border experience.

20 Edward W. Said, "Invention, Memory, and Place," in Landscape and Power, ed. W. J. T. Mitchell, 2nd ed. (Chicago: University of Chicago Press, 2002), 245. 
Limitations can be oppressive, but they can also be constructive. Identity depends on both adhering to and transgressing borders. By establishing and overriding boundaries, we claim-and reclaim-who we are. In maintaining its' boundaries, a nation affirms its core values and identity as rigid or porous and progressive, asserting power over us while denying or enabling human agency. In "developed" nations, borders are perceived as outlines reifying territorial sovereignty on a map and guaranteeing security within. Populist and nationalist political parties see them as a means of protecting citizens from "outsiders," casting victims of a civil war at home as villains sowing violence and uncertainty. This posturing denies the actual geography of the immigrant experience. Despite the constant negative media reporting around Middle Eastern and Muslim refugees in the West, 95\% of Syrian refugees are hosted in just five countries, none of which are in Europe or North America. ${ }^{21}$ The "unprecedented" influx of migrants from the global south to Europe is actually a trickle compared to the scale of such flows, and to internal displacement, in other parts of the world. Right-wing politicians use appeals to emotion to limit who can pass through borders and deflect responsibility, blaming foreigners for their countries' internal social and economic problems, and promoting an isolationist agenda that denies the immigrants' human rights. Their point of view is also divorced from economic realities; economists agree that the net fiscal impact of immigration generally lies within the range \pm 1 percent of GDP. ${ }^{22}$

When a person reestablishes boundaries within his life, he implies that categories and identities are not static but change over time (indeed, the country listed on my birth certificate literally no longer exists-it changed its name to the Republic of Poland after the fall of communism). When I call myself Polish, I acknowledge a link to my ancestors and a collective allegiance to that country. And when I call myself American, I likewise embrace the values that I associate with that label. I affirm that these identities should exist, although I often actively contest the political leadership in both countries. As I admit or reject elements of Polish and American culture, I internalize these identities and contribute to their outward complexity, decreasing their connotations with national sovereignty.

\section{Negotiating Transitional Spaces}

Like refugees, economic migrants who move abroad looking for a better life challenge the morality of existing national borders. These newcomers can make us more attuned to the world outside and to the pain of our fellow humans, or inspire xenophobic reactions and assign blame for social or economic problems. In questioning the purpose of our physical borders, migrants also lead us to re-evaluate our mental ones; by embodying different lifestyles and adapting (or not) to their new environments, they raise awareness of how social and cultural frontiers encourage some behaviors and denigrate others. They demonstrate that borders are permeable and identities are malleable by negotiating the norms of their new environment daily in contexts that alternately promote multiculturalism and assimilation.

The border can be a barrier that divides common ground and prevents individuals from living together, or a gateway to a new life. Both definitions-a rule that codifies distinction

21 Amnesty International, Syria's refugee crisis in numbers, September 4, 2015, https://www.amnesty.org/en/latest/news/2015/09/syrias-refugee-crisis-in-numbers/

22 Robert Rowthorn, "The Fiscal Impact of Immigration on the Advanced Economies," Oxford Review of Economic Policy 24, no. 3 (2008): 577. 
and a site of unpredictable opportunity-apply. Recently, the death at sea of tens of thousands of migrants seeking to immigrate to Europe from North Africa by evading official borders has become one of the most compelling social problems on our continent. Many are refugees that risk their lives, betting borders are the stuff that dreams are made of, only to find themselves exploited by human traffickers and turned away from the countries from which they seek safe haven. Crossing the border can thus be a turning point in a migrant's life or the latest in a series of setbacks, trials, and tribulations.

A border sets up a space "within" as being distinct from the space without and regulates what passes through. The very definition of a border varies across disciplines and languages and connotes ideas involving physical spaces-barriers, frontiers, fences, separations, boundaries, maps, districts, zones-populations affected-citizens, foreign nationals, diasporas-and associated issues-transit, transport, mobility, immigration, communication, national identity, safe passage, security, treaties, and more.

Enforced through laws and language, the border is a limit set, for example, to a country's territory. In English, the word border means both the outer limit of a place, and an ornamental edge (the word is derived from the French word bordure, or edge, Rand in German). The word implies power. According to Katarzyna Stokłosa and Gerhard Besier, "[T]he contemporary meaning of the word Grenze...involves the linear demarcation of a specific area of dominion or possession.... The German term Grenze does not do sufficient justice to the various types of borders in existence [whereas] the English terms 'frontier' and 'border'... establish the differences between a positive and a negative perception of borders." 23 That power is associated with the laws of nature. Grenze in German comes from the Slavic/Polish Granica, meaning border, boundary, or (mathematical) limit. Granica can also mean a limit to what a person can tolerate (granica wytrzymałości) or the elastic limit, which is the maximum extent to which a solid may be stretched (granica plastyczności). The border separates what is familiar from what is strange. Za granica (beyond the border) means à l'étranger in French-literally in a strange (foreign) place-and abroad or away from home in English.

Borders are instruments of possession: those with power over an area decide where to establish borders and how to enforce them. Their actions reveal that "borders are not merely geographical margins or territorial edges. They are complex social institutions, which are marked by tension between practices of border reinforcement and border crossing." 24 Such dynamics can also be expressed on a more local scale: through a barrier to entry, such as a security checkpoint in an office building that only admits employees; a rule preventing some behaviors, such as smoking, in public transportation; or informal notices, such as age limits posted at the entrance to a playground.

Perceptions of borders change over time and are not merely a result of physical proximity. In 2016, I was an artist in residence in the Val du Sambre, a region in the North of France near the Belgian border. Whereas in Polish/Ukrainian border towns like Przemyśl and in the Basque country, the border was a constant topic of conversation, in Maubeuge the issue hardly ever came up. That changed dramatically after the suicide bombing in the Brussels airport in early 2016. Suddenly the proximity to Belgium was a source of fear, a

\footnotetext{
23 Katarzyna Stokłosa and Gerhard Besier, European Border Regions in Comparison: Overcoming Nationalistic Aspects or Re-Nationalization? (New York: Routledge, 2014), 3.

24 Mezzadra and Neilson, Border as Method, 3, 7.
} 


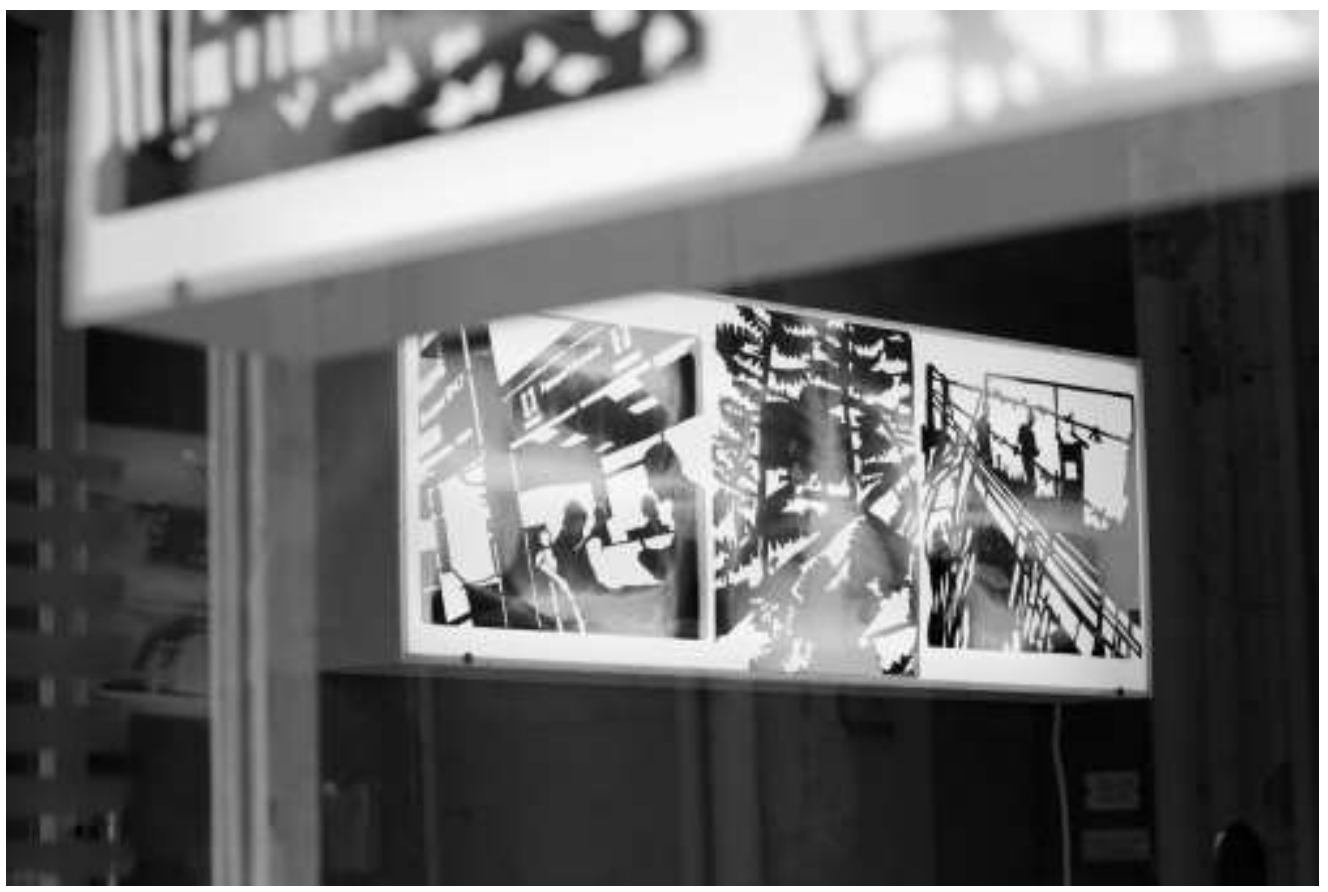

\section{Figure 6}

Kasia Ozga, Internal Frontier I and II, 2014, X-ray film on medical lightbox. Installation view, La Nuit de I'Instant 2014, Marseille, France. (photo: author)

reason to cancel school outings and public performances. The French government had declared a State of Emergency following the November terrorist attacks, banning protests in public places. After March, many school districts in the North followed suit by banning public art. Strangely enough, the state did not cancel the Euro soccer tournament or bat an eye at the Russian and English football fans clubbing each other with café tables in the streets of Marseille during the games. Apparently, limits on mobility across borders and tightened rules governing presence in public spaces are justified in some cases and not in others (especially when commercial interests are at stake). Borders are the result of power deployed to enforce behaviors and identities both within and without.

In naming the work Frontière Interne, I invited viewers to reflect on how we define, translate, and describe borders over time. The word frontier in English, which means border in French, has strong connotations with the exploration and colonization of unknown places. The French border is a boundary that defines France's territorial sovereignty, and the Frontière Interne is thus a kind of paradox referring to the boundaries within a unified body. The American frontier, as described by the Turner thesis, ${ }^{25}$ is a distant horizon, an extreme space where the spirit of future expansion lies. Moreover, the frontier comes from the word

25 Frederick Jackson Turner, The Significance of the Frontier in American History (Madison: State Historical Society of Wisconsin, 1894). 
front, the vanguard of the army, the part of the country that looks ahead and progresses outwards. The frontier of the Wild West is a springboard to freedom and lawlessness, and represents more of an opportunity than a limit to our actions. The Internal Frontier thus also refers to the shifting range of our potential movements. The frontiers imposed upon us and the frontiers that we put into place to frame our identities can thus be both limits and starting points for action.

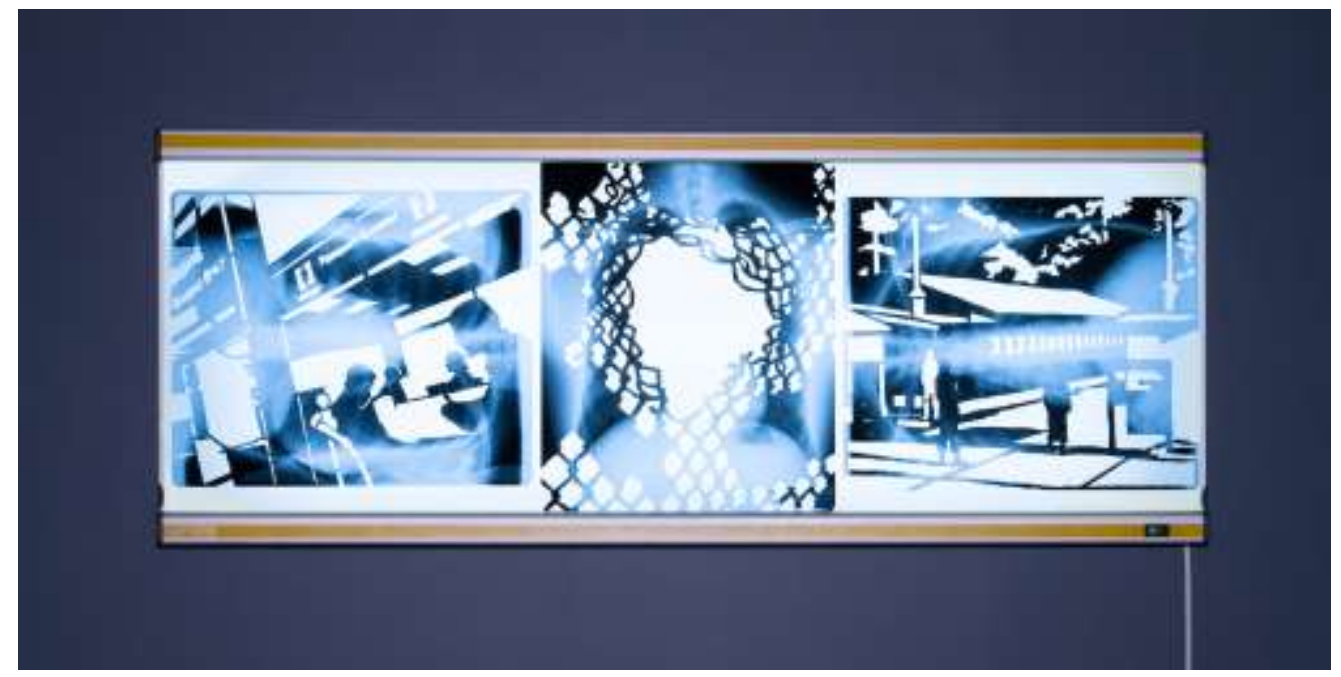

\section{Figure 7}

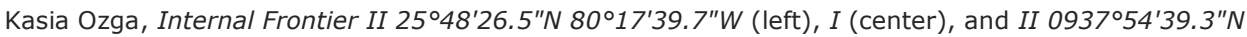
$126^{\circ} 41^{\prime} 52.0^{\prime \prime} E$ (right), 2013, X-ray film on medical lightbox. Installation view, Borders: Barrières Frontières La Off \#3 Exhibition, Centre culturel numérique Saint-Exupéry, Reims, France. (photo: author)

\section{Opening Bodies, Fostering Dialogue}

The Frontière Interne's ambiguity underscores the dual symbolism of the border as both barrier and springboard, simultaneously inhibiting and enabling interactions between individuals and select geographic locations. In the $x$-ray images, the physical site of transit is inscribed within the body, rather than something that we pass through, unharmed. The carved images highlight the narrative, temporal dimension of a site primarily considered in spatial terms. "When the subjective dimension of border crossings and struggles is introduced, the border acquires a temporal thickness and diversity that is not fully discernable within an analysis that systematically privileges spatial qualities." 26 Metaphorically, the human skin becomes a permeable membrane, rather than a fixed barrier, through which experiences of passage penetrate our core identities. The experience of moving from one area to another stays with the migrant, and becomes part of how he experiences the world.

\footnotetext{
26 Mezzadra and Neilson, Border as Method, 133.
} 
The works explore how our identities are formed as we pass through and reflect on the many borders-physical as well as mental-that we cross daily. The representations of borders in the series are ambiguous; they include vegetation, banal locations such as border control tollbooths, and anxiety-inducing fences patrolled by military personnel. Viewers are not given a ready explanation for the works' meanings but rather are asked to interpret why such scenes have been permanently inscribed on these very x-rays. Many learn about the use of biometric data in immigration control, for the first time. The plants and places become metaphors for experiences and barriers on a local and global scale. The border becomes not only an external, political reality, but also an internalized way of relating to spaces and situations.

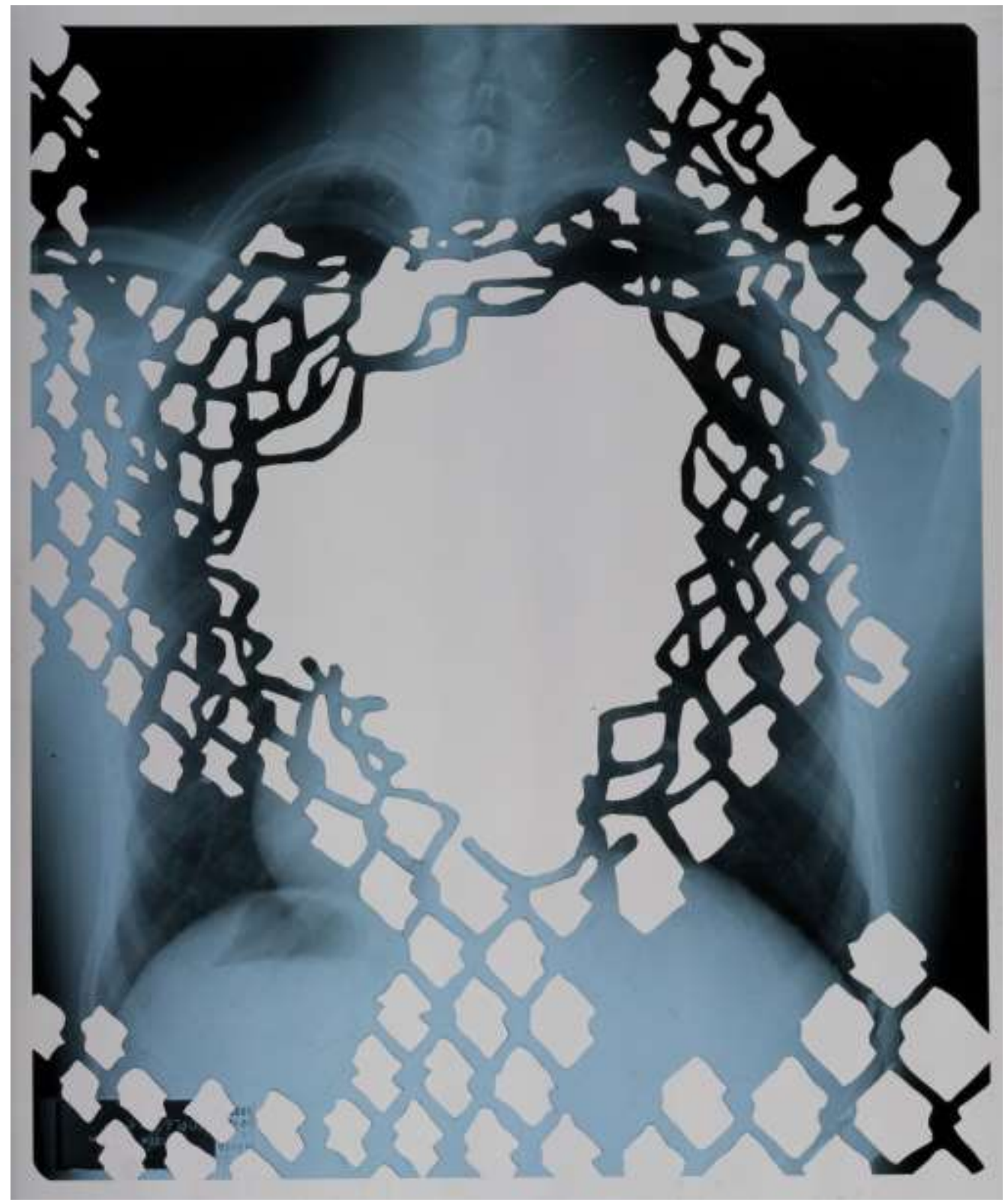

Figure 8

Kasia Ozga, Internal Frontier I, 2014, X-ray film on medical lightbox, 35.5 x $43 \mathrm{~cm}$. 
Though national borders are easier to identify than shifting cultural codes, the act of transgressing either is a form of expression that entails changing one's frame of mind by moving from the known to the unknown. Thus, we can look at border crossing as a metaphor for going beyond one's comfort zone and experiencing a sort of archetypal Jungian "Night Journey," a mythological descent to the underworld in which a hero confronts adversity within himself by voyaging outside of his existing environment. ${ }^{27}$ Whereas national borders influence each person's internal frontiers, many other factors likewise contribute to identity formation; these include interactions (collective undertakings, social support, family, and peer relationships) as well as cognitive, scholastic, and sociocultural influences. ${ }^{28}$ We negotiate between the varying demands of these constituencies as we define and redefine ourselves. ${ }^{29}$ We become who we are through the process of setting and crossing internal borders.

The images remind us that we all already cross symbolic borders in our daily lives. Rather than seeing the immigrant as "other," we appreciate him or her as one of us. The artworks transform migration from an isolated act to a shared human experience. We may not all be immigrants, but we can all potentially find ourselves in the migrant's position. Indeed, as the public advocacy campaign founded during the 1997 "documenta X" in Kassel reminds us, "No one is illegal." 30 By inspiring interpretation and encouraging fellow feeling, the Frontière works foster dialogue, "providing the possibility for antagonism to be transformed into 'agonism,'" and promoting the coexistence of multiple simultaneous discourses, institutions, and forms of border regimes. ${ }^{31}$

The Frontière Interne asks what art can contribute to our understanding of borders. Rather than providing an easy answer, the works invite viewers to reflect on how these barriers are internalized and experienced by migrants and how they are elaborated upon and enforced by those who put them into place.

(c) $\mathbf{B r}$ Attribution 4.0 United States License.

\section{ULIS D-Sork}

This journal is operated by the University Library System of the University of Pittsburgh as part of its D-Scribe Digital Publishing Program, and is co-sponsored by the University of Pittsburgh Press.

27 Carl Jung, The Archetypes and the Collective Unconscious, vol. 9, Part 1 of Collected Works, 2nd ed., trans. R. F. C. Hull, (Princeton: Princeton University Press, 1968).

28 Erik Erikson, Identity and the Life Cycle; Selected Papers (New York: International University Press. 1959).

29 Babies are born without a clear sense of distinction between themselves and the world around them; the mother is not seen and appreciated as an autonomous individual until infants are six months old and this separation (border) between the self and the mother is crucial for identity formation.

30 Hybrid Workspace, "No One is Illegal" Manifesto (documentaX: Kassel, 1997), https://noii2017.wordpress.com/portfolio/manifesto-english/

31 Chantal Mouffe, "For an Agonistic Public Sphere," in Democracy Unrealized, ed. Okwui Enwezor (Ostfeldern-Ruit: Hantje-Cantz Verlag, 2002), 90. 